\title{
Epidemiological study of pediatric severe sepsis in Argentina
}

\author{
Roberto Jabornisky, M.D., ${ }^{a}$ Silvia S. Sáenz, M.D., ${ }^{a}$ Patricia Capocasa, M.D., ${ }^{a}$ \\ Roxana Jaen, M.D., Rodolfo P. Moreno, M.D., ${ }^{a}$ Luis Landry, M.D., ${ }^{a}$ \\ Daniel Rufach, M.D., ${ }^{a}$ Silvia N. Santos, M.D., ${ }^{a}$ Mabel Berrueta, M.D., ${ }^{a}$ \\ Joseph Carcillo, M.D., Juan Carlos Vassallo, M.D., ${ }^{a}$ and the members of the Clinical \\ and Epidemiological Research Group in Pediatric Intensive Care of the Sociedad \\ Argentina de Pediatría
}

\begin{abstract}
Introduction. Severe sepsis (SS) is one of the leading causes of pediatric mortality in Argentina. The objective was to describe the epidemiological characteristics and to analyze risk factors associated with mortality from SS among patients hospitalized in pediatricintensivecareunits(PICU) in Argentina.
\end{abstract}

Population and Methods. Observational, prospective cohort study among patients with SS hospitalized in PICUs in Argentina from $8 / 1 / 2008$ to $9 / 30 / 2008$.

Results. Two thousand five hundred and fifty nine patients were admitted at 59 PICUs. A total of 315 patients (335 events) were included. Patients' median age was 8 months (1-182). The frequency was $13.8 \%$, and 28-day mortality was $31.6 \%$. Patients with a higher mortality were those who were coming from rural areas, had comorbidities at the time of admission or a history of cancer, had shock or acute respiratory distress syndrome (ARDS), were administered low-dose corticosteroids or vasoactive drugs or more than $60 \mathrm{ml} / \mathrm{kg}$ of fluid in the first hour and in the first 6 hours, and had severe malnutrition. Following adjustment by severity using a multivariate logistic regression model, only coming from a rural area, having shock or ARDS remained associated with 28-day mortality. Forty per cent of patients received antibiotics 60 minutes after diagnosis.

Conclusions. SS is an event with a high frequency and mortality in Argentina. In the severity adjusted multivariate analysis, only coming from a rural area, having ARDS and/or shock were associated with higher mortality.

Key words: sepsis, pediatrics, critical care, fluid therapy, mortality.

http: / / dx.doi.org/10.5546/ aap.2019.eng.S135

To cite: Jabornisky R, Sáenz SS, Capocasa P, Jaen R, et al. Epidemiological study of pediatric severe sepsis in Argentina. Arch Argent Pediatr.2019;117 Supl 3:S135-156.

\section{INTRODUCTION}

Severe sepsis (SS) is one of the leading causes of death among children in Argentina ${ }^{1}$ and the main cause among children dying in pediatric intensive care units (PICU) in the world. ${ }^{2-6}$

In 2003, Watson et al. estimated the incidence of sepsis in the general pediatric population of the USA to be $0.65 / 1000$ in children and 5.6/1000 in infants (more than 42000 cases/ year and about 4500 deaths/ year). ${ }^{2}$ Ten years later, they pointed out that mortality had decreased (from $10.6 \%$ to $8.9 \%$ ), but that the incidence and costs had increased $(0.89 / 1000$ children and five billion dollars per year, respectively). ${ }^{4}$

In 2017, the World Health Assembly adopted Resolution 70.7 to "improve the prevention, diagnosis and clinical management of sepsis." The Assembly recognized the scarcity of epidemiological data regarding the entity at an international level and urged Member States to take specific actions to reduce the burden of sepsis on public health and the economy. ${ }^{7,8}$

In Argentina, no epidemiological studies addressed pediatric SS; therefore, there is no essential information available to implement measures aimed at improving results.

The objective of this study was to describe the epidemiological characteristics and to analyze risk factors associated with mortality from SS among patients hospitalized in PICUs in Argentina.

\section{POPULATION AND METHODS}

In 2008 , a multicenter, observational, prospective cohort 
study of every event of SS was conducted among patients hospitalized in PICUs in Argentina.

Patients between 1 month old and 216 months old who were admitted to the PICU between $8 / 1 / 2008$ and $9 / 30 / 2008$ with a diagnosis of SS at the time of admission to the PICU or during their hospitalization were included. Patients who had been admitted to the PICU before 8/1/2008 but remained hospitalized during the study period were excluded. The definition of SS and the main outcome measures met the International Pediatric Sepsis Consensus Conference ${ }^{9}$ (Annex 1).

The selection of outcome measures that could potentially predict the course of the condition was initially based on what is reported in the literature on the possible impact of each of these on mortality from SS (Annex 1).

Terminally ill patients or patients with exclusive palliative care needs or adjustment of therapeutic effort, patients with a different diagnosis other than SS, patients admitted to the PICU during the study period but who had their first episode after 60 days of hospitalization in the unit; and patients that could not be followedup after admission to the unit were not included.

In March 2008, the enrollment was conducted by requesting a written informed consent to the head of the Division of each of the 130 PICUs (public and private) in the country ${ }^{10}$. For every participating PICU, two coordinators received an Access 1997-2007 database and a chart for each patient (Annex 2). Once completed, the chart was returned to the principal investigators for analysis.

All patients admitted to the PICU during the study period were registered and followed-up for up to 60 days after admission (if still hospitalized in the PICU). Those who met the inclusion criteria were followed-up until discharge from the PICU, or their death during hospitalization in the PICU, or after 28 days had elapsed since the start of the event. A new event was considered as such if it was unrelated to the previous event and if there was a time interval of at least 30 days between events.

\section{Statistical analysis}

Continuous outcome measures were summarized as mean and standard deviation (SD) or mean and range, depending on the distribution; categorical outcome measures were expressed in percentages. Student's $\mathrm{t}$ test or Wilcoxon test were used to compare continuous outcome measures, and the $\chi^{2}$ test for categorical outcome measures.
The association between the possible predicting factors and the primary endpoint (28-day mortality) was assessed using a bivariate and multivariate logistic regression analysis. Initially, a bivariate analysis between each of the independent or predictor variables $(x)$ and the dependent variable (y), 28-day mortality, was performed. It was analyzed if there was an individual association taking into account the change of crude $\beta$ coefficients and the Wald test for each of them. The cut-off point of $p$ was $<0.1$.

In the multivariate analysis, a parsimonious manual multiple model was designed. The cutoff point for accepting the variable when entering the multivariate model was $\mathrm{p}<0.05$. Overall calibration of the final model: the HosmerLemeshow test was done and a $p$ value $\geq 0.05$ was established in order not to reject the null hypothesis and to consider that it was globally well adapted to the model.

To limit data recording, categorization and analysis biases, training was provided in the participating PICUs before the start of the protocol. In order to minimize errors, the principal investigators reviewed database consistency, outliers, completeness and treatment of missing data in a standardized manner. Data were processed using the Stata 12.0 statistical package, Statacorp, Texas, USA.

\section{Ethical aspects}

Collected data were accessed in accordance with all ethical and legal regulations (Act 25326). Collected data were not used for any other purposes, and the identity of PICUs and patients' was kept confidential by means of dissociation (coded or reversely dissociated data).

This study was approved by the Ethics Committee, and the medical and teaching departments of the participating hospitals. It was conducted in the context of the National Committee of Emergencies and Critical Care of the Sociedad Argentina de Pediatría. No type of funding was received for its execution.

\section{RESULTS}

Out of 130 PICUs, 61 accepted to participate, representing 22 of the 24 national jurisdictions; data were sent by 59 PICUs, 14 of which had no cases of SS (Annex 3).

During the study period, 2559 patients were admitted to the 59 participating PICUs, 332 of whom had 353 events of SS (frequency: $13.8 \%$ ). Seventeen patients with 18 events were not 
included ( 3 events for being admitted before $8 / 1 / 08 ; 7$ for not meeting SS criteria; 2 for being admitted before 8/1/08 and not meeting SS criteria; 6 for lack of follow-up). That means that 315 patients with 335 events were analyzed (1 event: 315 patients; 2 events: 19 patients; 3 events: 1 patient) (Figure 1).

Table 1 shows general and patients' outcome data; Table 2, clinical aspects and treatments provided; Table 3, infection data.

Patients' mean age was 8 months (1-182). Nonsurviving patients were younger than survivors (mean: 6 months old vs. 13 months old, respectively). The median length of stay was 11 (1-119 days).

Diagnosis was made at the time of admission at the PICUs for 181 events (54\% versus $46 \%$ after admission); there were no differences in mortality between both groups. $80 \%$ of cases were referred from other hospitals.

There were 106 deaths ( $31.6 \%$ of events) in the PICUs; four of them among patients who had more than one event. The mortality in patients with one event (32\%) showed no statistical differences with nonsurviving patients who had more than one event $(20 \%)(p=0.24)$.

Twelve per cent of patients with microorganism identification did not receive the adequate antibiotic at the time of admission; however, non-identification of the microorganism at the time of admission was not associated with higher mortality $(p=0.7)$.

The patients with higher mortality were those with severe malnutrition, those who came from rural areas, those with comorbidities at the time of admission, those who had a history of cancer, and those with hospital-acquired infections. The presence of comorbidities doubled mortality (OR: $2.1 ; 95 \% \mathrm{CI}: 1.3-3.3$ ), and the presence of cancer tripled it (OR: 3.6; $95 \%$ CI: 1.5-8.3) (Table 4).

Patients who received more than $60 \mathrm{~mL} / \mathrm{kg}$ of fluid administration within the first hour or within the first six hours of treatment had a higher mortality. In addition, the probability of dying doubled in a clinically relevant and statistically significant way (OR: 1.9; $95 \%$ CI: 1.053.63; and OR: 1.8; 95 \% CI: 1.10-3.06, respectively) (Table 4).

The following outcome measures were included in the multivariate analysis: age, place of residence, nutritional status, severity at admission, concomitant disease, presence of shock, presence of acute respiratory distress syndrome (ARDS), fluids $>60 \mathrm{~mL} / \mathrm{kg}$ within the first hour, use of vasoactive drugs, treatment with

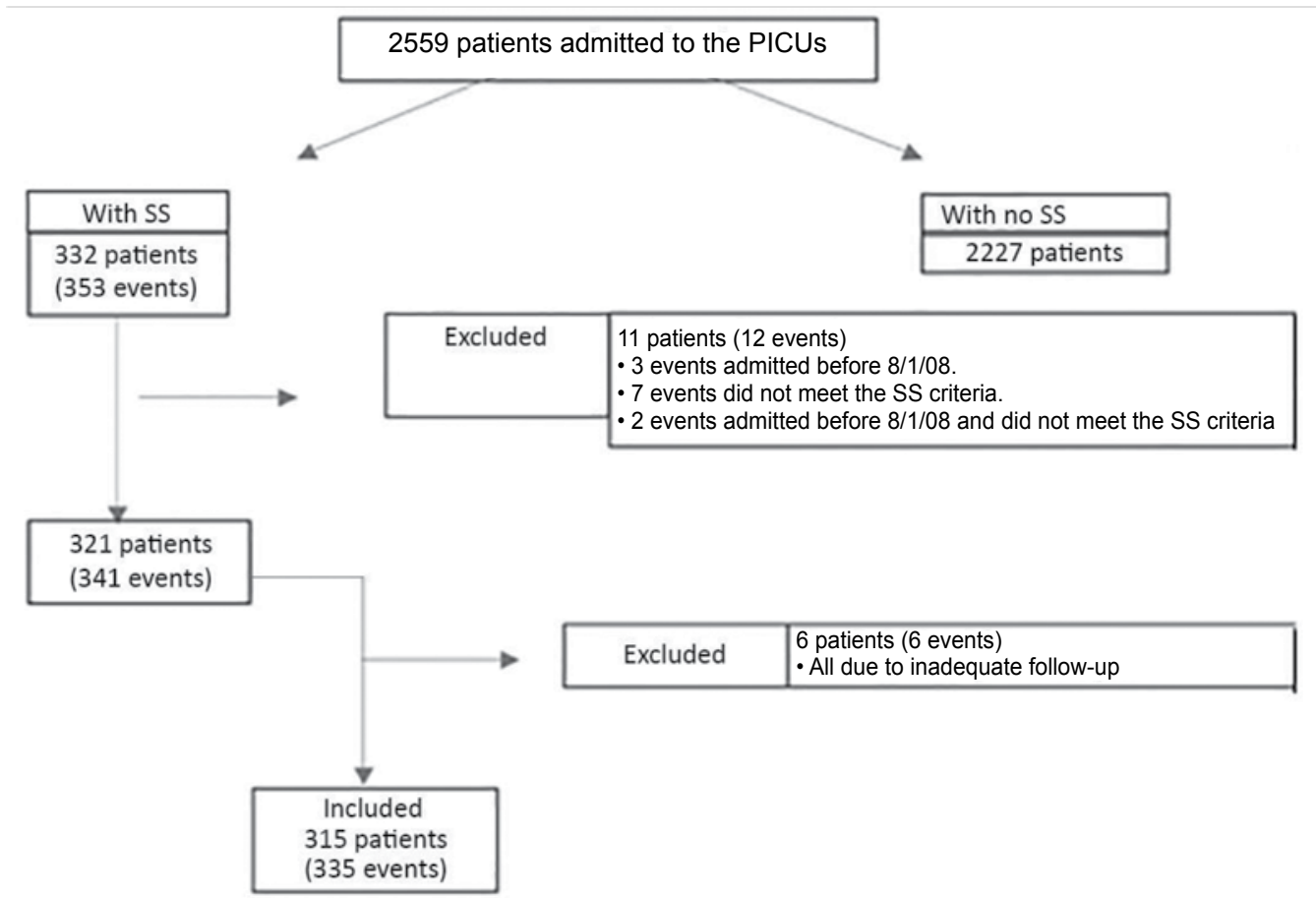

PICU: pediatric intensive care unit; SS: severe sepsis. 
TABLE 1. Characteristics of the population (n: 315 patients, 335 events)

\begin{tabular}{|c|c|}
\hline & Values \\
\hline \multicolumn{2}{|l|}{ Sex, n $(\%)^{1}$} \\
\hline Female & $151(47.9)$ \\
\hline Male & $164(52.1)$ \\
\hline \multirow[t]{2}{*}{ Age $^{1}$ (in months) } & $X=35$ \\
\hline & $\mathrm{M}_{\mathrm{e}}=8(1-182)$ \\
\hline \multirow[t]{2}{*}{ Weight (in kg) } & $X=12.6$ \\
\hline & $\mathrm{M}_{\mathrm{e}}=7.6(2.5-65)$ \\
\hline \multicolumn{2}{|l|}{ Nutritional status, $\mathrm{n}(\%)^{1}$} \\
\hline Adequate & $226(71.7)$ \\
\hline Moderate malnutrition & $57(18.1)$ \\
\hline Severe malnutrition & $32(10.2)$ \\
\hline \multicolumn{2}{|l|}{ Place of origin, $n(\%)^{1}$} \\
\hline Rural & $46(14.6)$ \\
\hline Urban & $269(85.4)$ \\
\hline History of surgery, n (\%) & $53(16.8)$ \\
\hline Emergency surgery & $24(7.6)$ \\
\hline Elective surgery & $29(9.2)$ \\
\hline History of trauma, $\mathbf{n}(\%)^{1}$ & $15(4.8)$ \\
\hline \multicolumn{2}{|l|}{ Concomitant diseases, $\mathbf{n}(\%)^{1,2}$} \\
\hline With concomitant disease & $161(51.1)$ \\
\hline Without concomitant disease & $154(48.9)$ \\
\hline Neurological disease & $21(6.7)$ \\
\hline Heart disease & $38(12.1)$ \\
\hline Respiratory disease & $41(13.0)$ \\
\hline Renal disease & $13(4.1)$ \\
\hline Gastrointestinal disease & $21(6.7)$ \\
\hline Hematologic disease (not cancer) & $12(3.8)$ \\
\hline Immunologic disease & $12(3.8)$ \\
\hline Cancer & $25(7.9)$ \\
\hline Metabolic disease & $4(1.3)$ \\
\hline Chromosomal/genetic disease & $28(8.9)$ \\
\hline $\begin{array}{l}\text { Uncategorized, disabling } \\
\text { chronic disease }\end{array}$ & $20(6.3)$ \\
\hline Extrinsic immunosuppression & $10(3.2)$ \\
\hline Transplant & $6(1.9)$ \\
\hline \multicolumn{2}{|l|}{ Length of stay in the PICU } \\
\hline Mean & 16 days \\
\hline Median & 11 days (1-119) \\
\hline \multicolumn{2}{|l|}{ Sequelae, n $(\%)^{3,4}$} \\
\hline Yes & $85(37.1)$ \\
\hline No & $125(54.6)$ \\
\hline Unknown & $19(8.3)$ \\
\hline \multirow{2}{*}{\multicolumn{2}{|c|}{$\begin{array}{l}\text { Mortality, } \mathbf{n}(\%)^{3} \\
\text { In the PICU }\end{array}$}} \\
\hline & \\
\hline Dead & $106(31.6)$ \\
\hline Alive & $229(68.4)$ \\
\hline \multicolumn{2}{|l|}{ After discharge from the PICU } \\
\hline Dead & $2(0.6)$ \\
\hline Alive & $186(55.5)$ \\
\hline $\begin{array}{l}\text { Unknown course after } \\
\text { discharge from the PICU }\end{array}$ & $41(12.2)$ \\
\hline
\end{tabular}

${ }^{1}$ Data analyzed based on the total number of patients with severe sepsis (315).

${ }^{2}$ Some patients had more than one concomitant disease or sequela.

${ }^{3}$ Data analyzed based on the total number of events of severe sepsis (335).

${ }^{4}$ Data analyzed based on the total number of survivors discharged from the PICU (total = 229).

$\mathrm{X}$ : mean; $\mathrm{M}_{\mathrm{e}}$ : median; kg: kilogram; PICU: pediatric intensive care unit.
TABLE 2. Clinical characteristics and treatments provided (number of events: 335)

\begin{tabular}{|c|c|}
\hline & Values in $\mathbf{n}(\%)^{1}$ \\
\hline \multicolumn{2}{|l|}{ Presence of hyperthermia } \\
\hline Yes & $296(88.4)$ \\
\hline No & 39 (11.6) \\
\hline PIM $^{2}$ & $\square=23.6(1-93), \mathrm{Me}=12$ \\
\hline \multicolumn{2}{|l|}{ Presence of shock } \\
\hline Yes & $277(82.7)$ \\
\hline No & $58(17.3)$ \\
\hline \multicolumn{2}{|l|}{ Presence of neurological dysfunction } \\
\hline Yes & $69(20.6)$ \\
\hline No & $266(79.4)$ \\
\hline \multicolumn{2}{|l|}{ Presence of ARDS } \\
\hline Yes & $196(58.5)$ \\
\hline No & $139(41.5)$ \\
\hline \multicolumn{2}{|l|}{ Presence of renal dysfunction } \\
\hline Yes & $56(16.7)$ \\
\hline No & $279(83.3)$ \\
\hline \multicolumn{2}{|l|}{ Presence of hematologic dysfunction } \\
\hline Yes & $103(30.8)$ \\
\hline No & $232(69.2)$ \\
\hline \multicolumn{2}{|l|}{ Presence of hepatic dysfunction } \\
\hline Yes & 49 (14.6) \\
\hline No & $286(85.4)$ \\
\hline \multicolumn{2}{|l|}{ Type of fluids used ${ }^{2}$} \\
\hline Saline solution & $296(88.4)$ \\
\hline Gelatin & $71(21.1)$ \\
\hline Albumin & $28(9.0)$ \\
\hline Plasma & $18(5.4)$ \\
\hline Other & $34(10.2)$ \\
\hline No fluids were used for expansion & $4(1.2)$ \\
\hline \multicolumn{2}{|l|}{ Use of vasoactive drugs ${ }^{2}$} \\
\hline Dopamine & $202(60.3)$ \\
\hline Adrenaline & $81(24.2)$ \\
\hline Noradrenaline & $72(21.5)$ \\
\hline Dobutamine & $59(17.6)$ \\
\hline Milrinone & $24(7.2)$ \\
\hline Nitroprusside & $1(0.3)$ \\
\hline Nitroglycerin & $4(1.2)$ \\
\hline Phenylephrine & $2(0.6)$ \\
\hline No vasoactive drugs were used & $54(16.1)$ \\
\hline \multicolumn{2}{|l|}{ AMV requirement ${ }^{2}$} \\
\hline Traditional ventilation & $307(91.6)$ \\
\hline High frequency ventilation & $3(1.0)$ \\
\hline NIV & $3(1.0)$ \\
\hline No data & $28(8.4)$ \\
\hline \multicolumn{2}{|c|}{ Use of renal function replacement therapies ${ }^{2}$} \\
\hline Peritoneal dialysis & $9(2.9)$ \\
\hline Hemodialysis & $3(1.0)$ \\
\hline Hemofiltration & $3(1.0)$ \\
\hline Hemodiafiltration & $1(0.3)$ \\
\hline $\begin{array}{l}\text { No renal function replacement } \\
\text { therapies were used }\end{array}$ & $322(96.1)$ \\
\hline \multicolumn{2}{|c|}{ Use of specific treatments in the first 72 hours $^{2}$} \\
\hline Heparin & $1(0.3)$ \\
\hline Albumin & $62(18.5)$ \\
\hline Immunoglobulin & $15(4.5)$ \\
\hline Insulin & $21(6.3)$ \\
\hline Low-dose corticosteroids & $57(17.0)$ \\
\hline High-dose corticosteroids & $29(8.7)$ \\
\hline
\end{tabular}

${ }^{1}$ Data analyzed based on the total number of events of severe sepsis (total $=335$ ).

${ }^{2}$ Some patients received more than one drug, type of fluid, type of ARM, renal function replacement therapy, or specific treatment.

x: mean; $\mathrm{M}_{\mathrm{e}}$ : median; PIM2: Pediatric Index of Mortality 2; ARDS: acute respiratory distress syndrome;

AMV: assistedmechanical ventilation; NIV: non-invasive ventilation. 
TABLE 3. Infection data (number of events: 335)

\begin{tabular}{lc}
\hline & Values in $\mathbf{n}(\%)^{\mathbf{1}}$ \\
\hline Source of the infection & \\
Hospital -acquired & $136(40.6)$ \\
Community-acquired & $191(57.0)$ \\
Unknown & $8(2.4)$ \\
Microorganism identification ${ }^{1}$ & \\
With identification & $213(63.6)$ \\
Without identification & $122(36.4)$ \\
Method used to identify the microorganism & \\
Culture & $151(70.9)$ \\
IgM & $3(1.4)$ \\
PCR & $9(4.2)$ \\
Other & $50(23.5)$ \\
Identified microorganism ${ }^{2}$ & \\
Gram (-) bacillus & $69(32.4)$ \\
Gram (-) coccus & $9(4.2)$ \\
Gram (+) coccus & $68(31.9)$ \\
Fungi & $4(1.9)$ \\
Virus & $45(21.1)$ \\
Other & $18(8.5)$ \\
Resistant microorganisms ${ }^{2}$ & $39(18.3)$ \\
Gram (-) bacillus, ESBL+ & $19(8.9)$ \\
Vancomycin-resistant enterococci & $1(0.5)$ \\
Methicillin-resistant staphylococci & $19(8.9)$ \\
Time of administration of the first antibiotic \\
dose ${ }^{1}$ \\
Within 60 minutes of diagnosis of SS \\
After 60 minutes of diagnosis of SS \\
No data & $195(58.2)$ \\
Adequate antibiotic ${ }^{2,3}$ & $131(39.1)$ \\
No & $9(2.7)$ \\
Yes & \\
Unknown & $25(11.7)$ \\
\hline & $140(65.7)$ \\
& $48(22.5)$ \\
\hline
\end{tabular}

${ }^{1}$ Data analyzed based on the total number of events of severe sepsis $($ total $=335)$.

${ }^{2}$ Data analyzed based on the total number of identified microorganisms (total $=213$ ).

${ }^{3}$ Antibiotic used at the time of the patient>s admission, which was consistent with the antibiogram of the microorganism subsequently identified.

IgM: immunoglobulin M; PCR: polymerase chain reaction; Gram (-): Gram-negative; Gram (+): Gram-positive;

ESBL: extended spectrum beta-lactamase; SS: severe sepsis.

low-dose corticosteroids. The final multivariate logistic regression model developed with a parsimonious model is robust and stable, and calibrates and discriminates adequately, with a Hosmer-Lemeshow test value of 0.67 and an area under the ROC (Receiver Operating Characteristic) curve of 0.76 (see Annex 4). This model shows an independent, statistically significant and clinically relevant association between the place of residence, the severity at admission, the presence of shock and ARDS with a higher 28-day mortality(Table 5).

\section{DISCUSSION}

To our knowledge, this is the first and only multicenter epidemiological study on pediatric SS in the PICUs of Argentina, with the participation of half of the existing PICUs in the country at that time.

The frequency, which was higher than that reported in other studies, was lower than the $16.3 \%$ value of the South American PICU subgroup that participated in the international Sepsis Prevalence, Outcomes, and Therapies (SPROUT) study. ${ }^{6,7}$

Mortality was higher than what has been reported in other studies (31.6\% versus $11 \%$ of South American PICUs in SPROUT), although it was consistent with the $30 \%$ mortality estimation of the Global Sepsis Initiative for developing countries. ${ }^{6,7,11}$

The association between a rural origin and a higher mortality rate, which has also been observed in other critical pediatric entities, may be due to "...disparities in the economic, demographic and cultural realities...". ${ }^{12-14}$

Infant prevalence and the percentage of patients with comorbidities were consistent with previous publications. However, unlike other studies, in this study, the age of the survivors doubled that of nonsurviving patients. . $5-7,12,14-16^{-1}$

The association between a higher mortality and the presence of shock and ARDS has also been reported by Odetola et al., and Landry et al. ${ }^{17,18}$

Treatments administered were consistent with the clinical practice guidelines (CPGs) recommendations of the time, in which the use of crystalloids, dopamine, and traditional mechanical ventilation prevailed. . $^{1920}$

Lower mortality was observed with the use of dopamine versus noradrenaline or adrenaline, although it may have only reflected the greater severity of treatment progression compared to patients treated with drugs other than dopamine. ${ }^{21,22}$

Consistent with recent publications, a higher fluid administration in the first hour and in the first six hours was associated with a greater number of deaths. However, this was not observed in our multivariate analysis following adjustment by severity, among other predictive outcome measures in the final model. ${ }^{23-27}$

Regarding the association of vasoactive drugs and fluid administration in the first hours with mortality, it is worth noting that this study was not initially designed to identify potential predictive outcome measures. 
S140 / Arch Argent Pediatr 2019;117 Supl 3:S135-S156 / Commissions, Committees and Working Groups

TABLE 4. Association between the clinical presentation or treatment provided and mortality (number of events: 335)

\begin{tabular}{|c|c|c|c|c|}
\hline Outcome measure & $\begin{array}{c}\text { Total } \\
(\mathrm{N}: 335)^{1} \\
\end{array}$ & $\begin{array}{c}\text { Survivors } \\
(\mathrm{N}: 229)^{2}\end{array}$ & $\begin{array}{c}\text { Nonsurviving patients } \\
\left(\mathrm{N}: \mathbf{1 0 6}^{2}\right.\end{array}$ & $p^{3}$ \\
\hline PIM (mean) & $\begin{array}{c}23.6 \\
\text { (95\% CI: } 20.7-26.6)\end{array}$ & $\begin{array}{c}18.0 \\
(95 \% \mathrm{CI}: 14.9-21.2)\end{array}$ & $\begin{array}{c}35.8 \\
\text { (95\% CI: } 29.8-41.8)\end{array}$ & $<0.0001$ \\
\hline \multicolumn{5}{|l|}{ Nutritional status, $\mathrm{n}(\%)$} \\
\hline $\begin{array}{l}\text { Adequate/Moderate malnutrition } \\
\text { Severe malnutrition }\end{array}$ & $\begin{array}{c}302(90.1) \\
33(9.9)\end{array}$ & $\begin{array}{l}211(69.9) \\
8(54.5)\end{array}$ & $\begin{array}{l}91(30.1) \\
15(45.5)\end{array}$ & 0.07 \\
\hline \multicolumn{5}{|l|}{ Place of origin, $\mathbf{n}(\%)$} \\
\hline $\begin{array}{l}\text { Rural } \\
\text { Urban }\end{array}$ & $\begin{array}{c}48(14.3) \\
287(85.7)\end{array}$ & $\begin{array}{c}21(43.8) \\
208(72.5)\end{array}$ & $\begin{array}{l}27(56.2) \\
79(27.5)\end{array}$ & 0.0001 \\
\hline \multicolumn{5}{|l|}{ Concomitant disease, $\mathbf{n}(\%)$} \\
\hline $\begin{array}{l}\text { Yes } \\
\text { No }\end{array}$ & $\begin{array}{l}170(50.7) \\
165(49.3)\end{array}$ & $\begin{array}{l}103(60.6) \\
126(76.4)\end{array}$ & $\begin{array}{l}67(39.4) \\
39(23.6)\end{array}$ & 0.002 \\
\hline \multicolumn{5}{|l|}{ Cancer, $\mathbf{n}(\%)$} \\
\hline $\begin{array}{l}\text { Yes } \\
\text { No }\end{array}$ & $\begin{array}{c}25(7.5) \\
310(92.5)\end{array}$ & $\begin{array}{c}10(40.0) \\
219(70.6)\end{array}$ & $\begin{array}{l}15(60.0) \\
91(29.4)\end{array}$ & 0.002 \\
\hline \multicolumn{5}{|c|}{ Diagnosis of SS at the time of admission at the PICU, $n(\%)$} \\
\hline $\begin{array}{l}\text { Yes } \\
\text { No }\end{array}$ & $\begin{array}{l}181(54.0) \\
154(46.0)\end{array}$ & $\begin{array}{l}121(66.9) \\
108(70.1)\end{array}$ & $\begin{array}{l}60(33.1) \\
46(29.9)\end{array}$ & 0.5 \\
\hline \multicolumn{5}{|l|}{ Source of SS, $\mathrm{n}(\%)$} \\
\hline $\begin{array}{l}\text { Hospital acquired } \\
\text { Community-acquired }\end{array}$ & $\begin{array}{l}142(42.4) \\
193(57.6)\end{array}$ & $\begin{array}{c}87(61.3) \\
142(73.6)\end{array}$ & $\begin{array}{l}55(38.7) \\
51(26.4)\end{array}$ & 0.02 \\
\hline \multicolumn{5}{|l|}{ Shock, n (\%) } \\
\hline $\begin{array}{l}\text { Yes } \\
\text { No }\end{array}$ & $\begin{array}{l}277(82.7) \\
58(17.3)\end{array}$ & $\begin{array}{l}183(66.1) \\
46(79.3)\end{array}$ & $\begin{array}{l}94(33.9) \\
12(20.7)\end{array}$ & 0.05 \\
\hline \multicolumn{5}{|l|}{ ARDS, n (\%) } \\
\hline $\begin{array}{l}\text { Yes } \\
\text { No }\end{array}$ & $\begin{array}{l}196(58.5) \\
139(41.5)\end{array}$ & $\begin{array}{l}121(61.7) \\
108(77.7)\end{array}$ & $\begin{array}{l}75(38.3) \\
31(22.3)\end{array}$ & 0.0002 \\
\hline \multicolumn{5}{|l|}{ Types of fluids, $\mathbf{n}(\%)$} \\
\hline \multicolumn{5}{|l|}{ Albumin } \\
\hline No & $307(91.6)$ & $208(67.8)$ & $99(32.2)$ & 0.4 \\
\hline \multicolumn{5}{|l|}{ Plasma } \\
\hline Yes & $18(5.4)$ & $7(38.9)$ & $11(61.1)$ & \\
\hline No & $317(94.6)$ & $223(70.0)$ & $95(30.0)$ & 0.006 \\
\hline 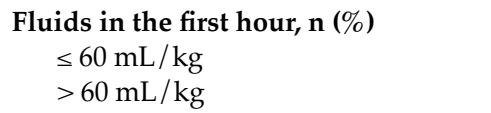 & $\begin{array}{c}286(85.4) \\
49(14.6)\end{array}$ & $\begin{array}{l}202(70.6) \\
27(55.1)\end{array}$ & $\begin{array}{l}84(29.4) \\
22(44.9)\end{array}$ & 0.03 \\
\hline $\begin{array}{l}\text { Fluids in the first } 6 \text { hours, } \mathbf{n}(\%) \\
\quad \leq 60 \mathrm{~mL} / \mathrm{kg} \\
>60 \mathrm{~mL} / \mathrm{kg}\end{array}$ & $\begin{array}{l}145(51.8) \\
135(48.2)\end{array}$ & $\begin{array}{l}109(75.1) \\
84(62.2)\end{array}$ & $\begin{array}{l}36(24.8) \\
51(37.8)\end{array}$ & 0.02 \\
\hline \multicolumn{5}{|l|}{ Use of vasoactive drugs } \\
\hline $\begin{array}{l}\text { Yes } \\
\text { No }\end{array}$ & $\begin{array}{l}281(84.0) \\
54(16.0)\end{array}$ & $\begin{array}{l}183(65.1) \\
46(85.2)\end{array}$ & $\begin{array}{l}98(34.9) \\
8(14.8)\end{array}$ & 0.004 \\
\hline \multicolumn{5}{|l|}{ Use of corticosteroids, $\mathbf{n}(\%)$} \\
\hline \multicolumn{5}{|l|}{ Corticosteroids in general } \\
\hline No & $249(74.3)$ & $181(72.7)$ & $68(27.3)$ & 0.004 \\
\hline \multicolumn{5}{|l|}{ Low-dose corticosteroids } \\
\hline Yes & $57(17.0)$ & $32(56.1)$ & $25(43.9)$ & \\
\hline No & $278(83.0)$ & $197(70.9)$ & $81(29.1)$ & 0.03 \\
\hline \multicolumn{5}{|l|}{ High-dose corticosteroids } \\
\hline Yes & $29(8.7)$ & $16(55.2)$ & $13(44.8)$ & \\
\hline No & $306(91.3)$ & $213(69.6)$ & $93(30.4)$ & 0.11 \\
\hline
\end{tabular}

${ }^{1}$ Data analyzed based on the total number of events of severe sepsis (total $=335$ ).

${ }^{2}$ Data analyzed based on the total number of survivors of severe sepsis events (total $=229$ ) and the total number of nonsurviving patients from severe sepsis events (total $=106$ ).

${ }^{3} \mathrm{P}$ calculated from the percentage of nonsurviving patients from the indicated outcome measures.

PIM: Pediatric Index of Mortality; SS: severe sepsis; ARDS: acute respiratory distress syndrome; $\mathrm{mL} / \mathrm{kg}$ : milliliters per kilogram;CI: confidence interval. 
The prevalence of Gram-positive coccus and Gram-negative bacillus among the identified microorganisms might be due to a change in the epidemiological profile of SS after the introduction of the pneumococcal, Haemophilus influenzae, and meningococcal vaccines, as pointed by Irvin et al. ${ }^{28}$

Weiss et al. reported a higher mortality associated with antibiotic administration after the first hour. ${ }^{29}$ In our study, $40 \%$ of patients received the first antibiotic dose after that time, and no differences in mortality were observed between the group that received it before and those who received it afterwards $(p=0.15)$.

After discharge from the PICU, (respiratory, neurological and renal) sequelae were mildly lower to that reported by Weiss et al. (37\% versus $45 \%)^{5}$

Some comments on the epidemiological study of pediatric severe sepsis in Argentina should be done. Although 10 years have elapsed since its execution, due to the volume of data observed and participating PICUs, it is an important study to establish guidelines on the diagnosis and treatment of SS in the country.

The prevalence and high mortality underscore the importance of the entity in Argentina, where a PICU with more than 10 beds is able to treat at least one patient with SS every day of the year. ${ }^{5}$

Ruth et al., using the International Classification of Diseases, $9^{\text {th }}$ revision (ICD-9) with the modified Angus criteria for PICUs, reported a mortality rate of $26.4 \% .{ }^{6}$ Our data may be more in line with this figure and reflect the inconveniences of Argentina's health system.

Han and Carcillo highlighted that early identification and aggressive resuscitation of newborn infants in septic shock by non-specialist physicians saved lives. ${ }^{30}$ In our study, $80 \%$ of patients were referred from other hospitals, which made it necessary to extend SS training to staff working outside these units.

When the study was conducted, the treatment paradigm favored an initial aggressive fluid

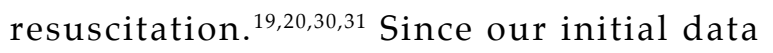
contradicted the prevailing paradigm, researchers were cautious about publishing our results, being wary of the possibility of these being biased and therefore invalid; the latter was, however, ruled out by later analysis. Although in the multivariate analysis this information lost relevance, a trend towards a higher mortality was observed in the group that received more than $60 \mathrm{~mL} / \mathrm{kg}$ of fluids in the first hour and in the first 6 hours, doubling the mortality rate in this group.

Studies conducted in later years challenged such paradigm. ${ }^{23}$ Van Paridon et al. reported an association between high fluid volumes in children with SS and an extended length of mechanical ventilation and stay in the PICU. ${ }^{32}$

Recent CPGs suggest the need to adequately assess higher fluid administration and infuse antibiotics and vasoactive drugs earlier..$^{33}$

In spite of the essentially descriptive nature of this study, it enabled to analyze SS in a large group of PICUs in Argentina. This type of study is useful to improve the quality of care for patients, provide information to improve their care, and facilitate health decision-making based on national data.

\section{CONCLUSIONS}

1. Pediatric SS is common in Argentina (13\% of admissions to PICUs), with a mortality rate of $31 \%$.

2. Most of the patients were infants (median age: 8 months), had previous comorbidities (50\%), came from urban areas $(85 \%)$, had a normal weight $(71 \%)$, and came from outside the PICUs (80\%).

3. $40 \%$ of patients received antibiotics one hour after the admission to the PICU.

4. Coming from a rural area, the presence of shock, having ARDS, adjusted by severity (estimated according to the Pediatric Index of Mortality 2 [PIM2]), were associated with a higher mortality in the multivariate analysis.

TABLE 5. Multivariate analysis

\begin{tabular}{lccc}
\hline Outcome measure & OR & $\mathbf{9 5 \%} \mathbf{C I}$ & $\mathbf{P}$ \\
\hline PIM2 & 1.02 & $1.01-1.03$ & $<0.0001$ \\
Rural area & 3.34 & $1.70-6.57$ & $<0.001$ \\
ARDS & 2.56 & $1.49-4.40$ & $<0.001$ \\
Shock & 2.24 & $1.07-4.70$ & 0.032 \\
\hline
\end{tabular}

OR: odds ratio; CI: confidence interval; PIM: Pediatric Index of Mortality;

ARDS: acute respiratory distress syndrome. 


\section{Collaborators}

Other members of the Clinical and Epidemiological

Research Group in Pediatric Intensive Care:

- Gladys Abreo de Almirón, M.D., Hospital Pediátrico "Juan Pablo II," Corrientes.

- José Federico Adén, M.D., Hospital de Niños "Dr. Héctor Quintana," San Salvador de Jujuy, Jujuy.

- José Luis Aguilar, M.D., Hospital de Niños "Dr. Héctor Quintana," San Salvador de Jujuy, Jujuy.

- Lidia Albano, M.D., Hospital Nacional "Profesor Alejandro Posadas," Haedo, province of Buenos Aires.

- Pilar Arias, M.D., Hospital General de Niños “Dr. Ricardo Gutiérrez," Buenos Aires.

- Roberto Ariel, M.D., Hospital Materno Infantil "San Roque," Paraná, Entre Ríos.

- Ariel Aruj, M.D., Hospital Italiano de San Justo, San Justo, province of Buenos Aires.

- Santiago Ayala Torales, M.D., Hospital Municipal Materno Infantil de San Isidro "Dr. Carlos Gianantonio," San Isidro, province of Buenos Aires.

- Irma Azar, M.D., Hospital de Niños de la Santísima Trinidad, Córdoba.

- Gloria Baggio, M.D., Hospital de Niños “Víctor J. Vilela," Rosario, Santa Fe.

- Martín Balacco, M.D., Hospital "Andrés Isola," Puerto Madryn, Chubut.

- Amparo Baldironi, M.D., Hospital Pediátrico del Niño Jesús, Córdoba.

- Edgardo Banille, M.D., Hospital de Niños de la Santísima Trinidad, Córdoba.

- Margarita Batista, M.D., Hospital de Alta Complejidad "Presidente Juan Domingo Perón," Formosa.

- Ana Carola Blanco, M.D., Hospital Interzonal General de Agudos "Vicente López y Planes," General Rodríguez, province of Buenos Aires.

- Santiago A. Blasón, M.D., Hospital Municipal de Olavarría "Dr. Héctor M. Cura," Olavarría, province of Buenos Aires.

- Rodrigo Burgos Pratx, M.D., Hospital de Ushuaia, Tierra del Fuego.

- Marisa Cabezas, M.D., Hospital de Niños "Víctor J. Vilela," Rosario, Santa Fe.

- Ariel Cacciamano, M.D., Hospital Infantil de Córdoba, Córdoba.

- Daniel Caffarone, M.D., Hospital de Ushuaia, Tierra del Fuego.

- Daniel Capra, M.D., Hospital Nacional “Profesor Alejandro Posadas," Haedo, province of Buenos Aires.
- Gustavo Caprotta, M.D., Hospital de Trauma y Emergencias "Dr. Federico Abate," Malvinas Argentinas, province of Buenos Aires.

- Gerardo Carrillo, M.D., Hospital Público Descentralizado "Dr. Guillermo Rawson", San Juan.

- Silvia Castellano, M.D., FLENI, Buenos Aires.

- Rosana Chiabrando, M.D., Sanatorio Franchin, Buenos Aires.

- Sandra Chuchuy, M.D., Hospital de Niños "Niño Jesús de Praga," Salta.

- Karina Andrea Cinquegrani, M.D., Hospital de Alta Complejidad "El Cruce Néstor Carlos Kirchner," Florencio Varela, province of Buenos Aires.

- Carmen Colman, M.D., Hospital Pediátrico “Dr. Avelino Castelán," Resistencia, Chaco.

- Analía Constantini, M.D., Hospital Regional de Río Gallegos, Santa Cruz.

- Patricia Correa, M.D., Hospital Pediátrico “Dr. Humberto J. Notti," Mendoza.

- Brenda Davidson, M.D., Sanatorio Mitre, Buenos Aires.

- Carlos Dávila, M.D., Hospital Provincial "Dr. Eduardo Castro Rendón," Neuquén.

- Elizabeth Beatriz Dávila, M.D., Hospital Pediátrico "Dr. Humberto J. Notti," Mendoza.

- Gustavo Debaisi, M.D., Hospital de Niños "Dr. Pedro de Elizalde," Buenos Aires.

- Juan Díaz, M.D., Hospital Privado de Córdoba, Córdoba.

- Santiago Esquivel, M.D., Hospital Interzonal General de Agudos "Vicente López y Planes," General Rodríguez, province of Buenos Aires.

- Julio Faríast, M.D., Hospital General de Niños "Dr. Ricardo Gutiérrez," Buenos Aires.

- Ricardo A. Festino, M.D., Hospital Universitario Austral, Pilar, province of Buenos Aires.

- Tomas Fiori Bimbi, M.D., Department of Pediatrics and Neonatology (Servicio de Neonatología y Pediatría, SENYP) - Centro Integral de Atención Pediátrica (CIAP), San Miguel de Tucumán, Tucumán.

- Hugo Fleitas, M.D., Hospital Interzonal General de Agudos “Dr. Abraham Piñeyro," Junín, province of Buenos Aires.

- Doris Elisa Flores, M.D., Hospital Público Materno Infantil, Salta.

- Gabriel Frey, M.D., Sanatorio Aconcagua, Córdoba.

- Mauro Daniel Juan García, M.D., ICU 45, Hospital Nacional de Pediatría "Prof. Dr. Juan P. Garrahan," Buenos Aires.

- Cristian García Roig, M.D., Sanatorio Mater Dei, 
Buenos Aires.

- Julio César Gómez, M.D., Hospital Provincial de Rosario, Rosario, Santa Fe.

- María Paula González, M.D., Hospital Público Materno Infantil, Salta.

- Osvaldo Rubén González Carrillo, M.D., Hospital de Niños "Dr. Orlando Alassia," Santa Fe.

- Elena Guaita, M.D., Hospital de Niños “Dr. Pedro de Elizalde," Buenos Aires.

- Karina Guiamet, M.D., Hospital Italiano de La Plata, La Plata, province of Buenos Aires.

- María Griselda Gutiérrez, M.D., Sanatorio de Niños de Rosario, Rosario, Santa Fe.

- Marcelo Itharte, M.D., Hospital Materno Infantil "San Roque," Paraná, Entre Ríos.

- Eugenia Kenny, M.D., FLENI, Buenos Aires.

- In JaKo, M.D., Hospital General de Niños “Dr. Ricardo Gutiérrez," Buenos Aires.

- Federico Laffaye, M.D., Hospital Provincial “Dr. Eduardo Castro Rendón,” Neuquén.

- Oscar Lazzuri, M.D., Clínica Sucre, Córdoba.

- Andrés Little, M.D., Hospital Zonal “Dr. Ramón Carrillo," Bariloche, Río Negro.

- Ricardo Magliola, M.D., ICU 35, Hospital Nacional de Pediatría "Prof. Dr. Juan P. Garrahan," Buenos Aires.

- Aurora Luján, M.D., Sanatorio Aconcagua, Córdoba.

- Claudio Manara, M.D., ICU 35, Hospital Nacional de Pediatría "Prof. Dr. Juan P. Garrahan," Buenos Aires.

- Mariela Manrique, M.D., Hospital Público Descentralizado “Dr. Guillermo Rawson," San Juan.

- Eduardo Mari, M.D., Hospital del Niño de San Justo, San Justo, province of Buenos Aires.

- Cristian Martinez, M.D., Hospital Italiano de Buenos Aires, Autonomous City of Buenos Aires.

- Ezequiel Martínez del Valle, M.D., Hospital Universitario Austral, Pilar, province of Buenos Aires.

- María Silvia Maurizio Dama, M.D., Nuevo Hospital Río Cuarto, Río Cuarto, Córdoba.

- Pablo Minces, M.D., Hospital Italiano de Buenos Aires, Autonomous City of Buenos Aires.

- María José Montes, M.D., Hospital de Niños de la Santísima Trinidad, Córdoba.

- Ezequiel Monteverde, M.D., Sanatorio Mater Dei, Buenos Aires.

- Silvina Morales, M.D., Hospital de Trauma y Emergencias "Dr. Federico Abate," Malvinas Argentinas, province of Buenos Aires.
- Ernesto Moreno, M.D., Hospital de Alta Complejidad "Presidente Juan Domingo Perón," Formosa.

- Marta Juana Mosciaro, M.D., Hospital Pediátrico “Dr. Humberto J. Notti," Mendoza.

- Eduardo Motto, M.D., ICU 44, Hospital Nacional de Pediatría "Prof. Dr. Juan P. Garrahan," Buenos Aires.

- Ivonne Name, M.D., Sanatorio Mitre, Buenos Aires.

- Mauro Nieto, M.D., Hospital Regional de Río Gallegos, Santa Cruz.

- Gabriel Nievas, M.D., Nuevo Hospital Río Cuarto, Río Cuarto, Córdoba.

- Noemí Olivello White, M.D., Hospital Pediátrico "Juan Pablo II," Corrientes.

- Valeria Oviedo, M.D., Hospital Provincial de Rosario, Rosario, Santa Fe.

- Rodolfo Pacce, M.D., Hospital de Niños “Dr. Orlando Alassia," Santa Fe.

- Gladys Aurora Palacio, M.D., Hospital General de Niños “Dr. Ricardo Gutiérrez," Buenos Aires.

- Gabriela Parma, M.D., Hospital Alemán, Buenos Aires.

- Gabriel Paz, M.D., Clínica del Sol, Córdoba.

- Claudia Pedraza, M.D., Department of Cardiovascular Surgery, Hospital de Niños Interzonal de Agudos Especializado en Pediatría "Superiora Sor María Ludovica," La Plata, province of Buenos Aires.

- Matías Penazzi, M.D., Hospital del Niño de San Justo, San Justo, province of Buenos Aires.

- Susana Pérez, M.D., Hospital Provincial "Lucio Molas," Santa Rosa, La Pampa.

- Pedro Portero, M.D., Hospital Interzonal General de Agudos "Dr. Abraham Piñeyro," Junín, province of Buenos Aires.

- Melina Rabino, M.D., Hospital de Niños Interzonal de Agudos Especializado en Pediatría “Superiora Sor María Ludovica," La Plata, province of Buenos Aires.

- María Elena Ratto, M.D., Hospital de Niños Interzonal de Agudos Especializado en Pediatría "Superiora Sor María Ludovica," La Plata, province of Buenos Aires.

- Norma Raúl, M.D., Hospital Italiano de La Plata, La Plata, province of Buenos Aires.

- Oscar Recupero, M.D., Hospital de Niños Interzonal de Agudos Especializado en Pediatría “Superiora Sor María Ludovica," La Plata, province of Buenos Aires.

- Edgardo Rodríguez, M.D., FLENI, Buenos Aires

- Daniel Rodríguez, M.D., Hospital “Andrés 
Isola," Puerto Madryn, Chubut.

- Marcelo A. Rojo, M.D., Hospital Municipal de Olavarría “Dr. Héctor M. Cura," Olavarría, province of Buenos Aires.

- Graciela Romero, M.D., Hospital de Niños “Eva Perón," San Fernando del Valle de Catamarca, Catamarca.

- Walter Rua, M.D., Hospital de Niños "Niño Jesús de Praga," Salta.

- Gladys Saa, M.D., Fundación Favaloro, Buenos Aires.

- Rafael Sánchez Bocco, M.D., Hospital Pediátrico del Niño Jesús, Córdoba.

- Jorge Sasbón, M.D., ICU 45, Hospital Nacional de Pediatría “Prof. Dr. Juan P. Garrahan," Buenos Aires.

- Silvia Sciacaluga, M.D., Sanatorio de Niños de Rosario, Rosario, Santa Fe.

- Ricardo Seco, M.D., Hospital de Niños "Eva Perón," San Fernando del Valle de Catamarca, Catamarca.

- Andrea Suppo, M.D., Hospital Zonal “Dr. Adolfo Margara," Trelew, Chubut.

- Lisandro Torre, M.D., Hospital Zonal "Dr. Adolfo Margara," Trelew, Chubut.

- José Torres, M.D., Hospital Privado de Córdoba, Córdoba.

- Carina Vega, M.D., Hospital Alemán, Buenos Aires.

- Alejandra Vecchi, M.D., Department of Cardiovascular Surgery, Hospital de Niños Interzonal de Agudos Especializado en Pediatría "Superiora Sor María Ludovica," La Plata, province of Buenos Aires.

- Fabio Veloso, M.D., Hospital Provincial "Lucio Molas," Santa Rosa, La Pampa.

- Gregorio Weller, M.D., ICU 44, Hospital Nacional de Pediatría "Prof. Dr. Juan P. Garrahan," Buenos Aires.

- Alicia Yunis, M.D., Hospital Público Provincial de Pediatría “Dr. Fernando Barreyro," Posadas, Misiones.

\section{REFERENCES}

1. SAP-UNICEF. Salud Materno-infanto-juvenil 2017 en cifras. [Accessed on: October $25^{\text {th }}, 2018$ ]. Available at: http: / / www.sap.org.ar/uploads / archivos / files_2017en-cifras_1505316814.pdf.

2. Watson RS, Carcillo JA, Linde-Zwirble WT, Clermont G, et al. The epidemiology of severe sepsis in children in the United States. Am J RespirCrit Care Med. 2003; 167(5):695701.

3. Jaramillo-Bustamante JC, Marín-Agudelo A, FernándezLaverde M, Bareño-Silva J. Epidemiology of sepsis in pediatric intensive care units: first Colombian multicenter study. PediatrCrit Care Med. 2012; 13(5):501-8.

4. Hartman ME, Linde-Zwirble WT, Angus DC, Watson RS.
Trends in the epidemiology of pediatric severe sepsis. PediatrCrit Care Med. 2013; 14(7):686-93.

5. Weiss S, Fitzgerald JC, Pappachan J, Wheeler D, et al. Global epidemiology of pediatric severe sepsis: the sepsis prevalence, outcomes, and therapies study. Am J RespirCrit Care Med. 2015; 191(10):1147-57.

6. Ruth A, McCracken CE, Fortenberry JD, Hall M, et al. Pediatric severe sepsis: current trends and outcomes from the Pediatric Health Information Systems database. PediatrCrit Care Med. 2014; 15(9):828-38.

7. World Health Organization. Improving the prevention, diagnosis and clinical management of sepsis. $70^{\circ}$ World Health Assembly. 29 May 2017. [Accessed on: November $30^{\text {th }}$, 2017]. Available at: http: / / apps.who.int/gb/ebwha/pdf_files / WHA70 / A70_R7en.pdf.

8. Kissoon N, Reinhart K, Daniels R, Machado MF, et al. Sepsis in Children: Global Implications of the World Health Assembly Resolution on Sepsis. PediatrCrit Care Med. 2017; 18(12):e625-7.

9. Goldstein B, Giroir B, Randolph A; International Consensus Conference on Pediatric Sepsis. International pediatric sepsis consensus conference: definitions for sepsis and organ dysfunction in pediatrics. PediatrCrit Care Med. 2005; 6(1):2-8.

10. Rufach D, Santos S, Vassallo J, et al. Relevamiento de UCIP en la República Argentina. Presentación Oral en: V Congreso Argentino De Emergencias y Cuidados Críticos Pediátricos; 25-28 de Mayo 2005. Complejo Costa Casino. Corrientes: SAP; 2005.

11. Kissoon N, Carcillo JA, Espinosa V, Argent A, et al. World Federation of Pediatric Intensive Care and Critical Care Societies: GlobalSepsis Initiative. PediatrCrit Care Med. 2011; 12(5):494-503.

12. Liu M, Zhang Q, Lu M, Kwon C, et al. Rural and urban disparity in health services utilization in China. Med Care. 2007; 45(8):767-74.

13. Romanow R. Buildings on Values: The Future of the Health Care in Canada: final report. Saskatoon: Privy Council; 2002.

14. Vila Pérez D, Jordan I, Esteban E, García-Soler P, et al. Prognostic factors in pediatric sepsis study, from the Spanish Society of Pediatric Intensive Care. Pediatr Infect Dis J. 2014; 33(2):152-7.

15. Balamuth F, Weiss S, Neuman M, Scott H, et al. Pediatric Severe Sepsis in U.S. Children's Hospitals. PediatrCrit Care Med. 2014; 15(9):798-805.

16. Monteverde E, Fernández A, Poterala R, Vidal N, et al. Characterization of pediatric patients receiving prolonged mechanical ventilation. PediatrCrit Care Med. 2011; 12(6):e287-91.

17. Odetola FA, Gebremariam A, Freed GL. Patient and hospital correlates of clinical outcomes and resource utilization in severe pediatric sepsis. Pediatrics. 2007; 119(3):487-94.

18. Landry L, Saporiti A, VasalloJ, Jmelnitsky L, et al. Síndrome de disfunción múltiple de órganos secundario a infecciones severas. MedInfant. 1994; 1:133-7.

19. Carcillo JA, Fields AI; American College of Critical Care Medicine Task Force Committee Members. Clinical practice parameters for hemodynamic support of pediatric and neonatal patients in septic shock. Crit Care Med. 2002; 30(6):1365-78.

20. Dellinger RP, Levy MM, Carlet JM, Bion J, et al. Surviving Sepsis Campaign: International guidelines for management of severe sepsis and septic shock: 2008. Intensive Care Med. 2008; 34(1):17-60.

21. Ventura AM, Shieh HH, Bousso A, Góes PF, et al. DoubleBlind Prospective Randomized Controlled Trial of 
Dopamine Versus Epinephrine as First-Line Vasoactive Drugs in Pediatric Septic Shock. Crit Care Med. 2015; 43(11):2292-302.

22. Ramaswamy KN, Singhi S, Jayashree M, Bansal A, et al. Double-Blind Randomized Clinical Trial Comparing Dopamine and Epinephrine in Pediatric Fluid- Refractory Hypotensive Septic Shock. PedriatrCrit Care Med. 2016; 17(11):e502-12.

23. Maitland K, Kiguli S, Opoka RO, Engoru C, et al. Mortality after fluid bolus in African children with severe infection. N Engl J Med. 2011; 364(26):2483-95.

24. Ford N, Hargreaves S, Shanks L. Mortality after fluid bolus in children with shock due to sepsis or severe infection: A systematic review and meta-analysis. PLoS One. 2012; 7(8):e43953.

25. Opiyo N, Molyneux E, Sinclair D, Garner P, etal. Immediate fluid management of children with severe febrile illness and signs of impaired circulation in low- income settings: A contextualized systematic review. BMJ Open. 2014; 4(4):e004934.

26. Atkinson SJ, Cvijanovich NZ, Thomas NJ, Allen GL, et al. Corticosteroids and pediatric septic shock outcomes: a risk stratified analysis. PLoS One. 2014; 9(11):e112702.

27. Funk D, Doucette S, Pisipati A, Dodek P, et al. Low-dose corticosteroid treatment in septic shock: a propensity- matching study. Crit Care Med. 2014; 42(11):2333-41.

28. Irwin AD, Drew RJ, Marshall P, Nguyen K, et al. Etiology of childhood bacteremia and timely antibiotics administration in the emergency department. Pediatrics. 2015; 135(4):63542.

29. Weiss SL, Fitzgerald JC, Balamuth F, Alpern ER, et al. Delayed antimicrobial therapy increases mortality and organ dysfunction duration in pediatric sepsis. Crit Care Med. 2014; 42(11):2409-17.

30. Han YY, Carcillo JA, Dragotta MA, Bills DM, et al. Early reversal of pediatric-neonatal septic shock by community physicians is associated with improved outcome. Pediatrics. 2003; 112(4):793-9.

31. Carcillo JA, Davis AL, Zaritsky A. Role of early fluid resuscitation in pediatric septic shock. JAMA. 1991; 266(9):1242-5.

32. Van Paridon BM, Sheppard C, García Guerra G, Joffe AR; Alberta Sepsis Network. Timing of antibiotics, volume, and vasoactive infusions in children with sepsis admitted to intensive care. Crit Care. 2015; 19:293.

33. Davis AL, Carcillo JA, Aneja RK, Deymann AJ, et al. American College of Critical Care MedicineClinical Practice Parameters for Hemodynamic Support of Pediatric and Neonatal Septic Shock. Crit Care. 2017; 45(6):1061-93. 


\section{ANNEX 1. \\ OPERATIONAL DEFINITION OF OUTCOME MEASURES AND DESCRIPTION OF FACTORS THAT WERE CONSIDERED PREDICTORS OF MORTALITY}

The pediatric systemic inflammatory response syndrome (SIRS), sepsis, severe sepsis, septic shock, ARDS outcome measures are in accordance with the International Consensus Conference on Pediatric Sepsis. ${ }^{9}$

a. Outcome measures

I. SIRS: nonspecific inflammatory process that occurs after a trauma, an infection, burn injuries, acute pancreatitis, or surgical procedures.

SIRS diagnosis: the presence of at least 2 of the following 4 criteria, one of which must be abnormal temperature or leukocyte count:

- Core temperature of $>38.5^{\circ} \mathrm{C}$ or $<36{ }^{\circ} \mathrm{C}$.

- Altered heart rate (HR):

o Tachycardia: HR > 2 SD above normal for age in the absence of external stimuli, chronic drugs, painful stimuli, or otherwise unexplained persistent elevation during 30 minutes-4 hours.

o or for children $<1$ year old, bradycardia: $\mathrm{HR}<10^{\text {th }}$ percentile, in the absence of vagal stimulus, $\beta$ blocker drugs, congenital heart disease, or otherwise unexplained depression during more than 30 minutes.

- Respiratory rate $>2$ SD above normal for age or mechanical ventilation not related to neuromuscular disease or general anesthesia.

- Leukocyte count elevated or depressed for age (not secondary to chemotherapy-induced leukopenia) or $>10 \%$ immature neutrophils.

\section{Sepsis}

SIRS associated with a suspected or proven infection.

\section{Severe sepsis}

Sepsis plus one of the following:

- Cardiovascular organ dysfunction or

- ARDS or

- 2 or more other organ dysfunctions.

\section{Septic shock}

Sepsis and cardiovascular organ dysfunction.

V. ARDS: a severe respiratory failure due to a noncardiogenic pulmonary edema, caused by an increased alveolar-capillary barrier permeability and secondary to an acute lung injury.

- ARDS diagnosis: presence of arterial oxygen partial pressure $\left(\mathrm{PaO}_{2}\right)<200 \mathrm{mmHg}$, bilateral pulmonary infiltrates, acute onset, no signs of left heart failure.

VI. Proven infection: objective pathogen identification through one or more methods, which include the culture of patient's samples, Gram staining, tissue staining, CRP, or other well-known methods.

VII. Suspected infection: a very suggestive clinical presentation, high probability of infection at clinical exam, imaging, laboratory tests. Examples include perforated viscus, chest radiography consistent with pneumonia, petechiae, purpura fulminans, or white blood cells in a normally sterile body fluid.

VIII. Elective surgery: major surgery (other than tracheostomy) within 2 weeks prior to admission.

IX.Emergency surgery: unscheduled surgery within 24 hours of onset of symptoms.

X. Comorbidities:medical conditions that can reasonably last for, at least, a year, unless death occurs, which compromise several organs or a system, severe enough to require specialized medical care or referral to a tertiary care facility. (In Annex 2. Data collection record, point 12 shows different conditions).

XI. PICU-acquired sepsis: sepsis identified at $48 \mathrm{~h}$ of PICU admission or later.

XII. Hospital-acquired sepsis: sepsis identified at $48 \mathrm{~h}$ of hospital admission or later. 
XIII. Vasoactive drugs: defined in Annex 2. Data collection record, point 15.

XIV. Adequate nutritional status: indicates a history of weight loss of less than $5 \%$ in the last 6 months (data collected from parents during history taking), but there are recent data showing appetite recovery, with no visible subcutaneous fat loss. (Overall subjective assessment).

XV. Moderate malnutrition: indicates a 5\%-10\% weight loss (data obtained during history taking) without regaining it, low dietary intake, and mild to moderate subcutaneous fat loss. (Overall subjective assessment).

XVI. Severe malnutrition: indicates a weight loss of more than $10 \%$, with severe loss of subcutaneous fat tissue and muscle wasting; most of the times along with edema. (Overall subjective assessment).

For this analysis, the severe malnutrition outcome measure was dichotomized into "yes" / "no", considering the adequate and moderate malnutrition categories as lack of severe malnutrition.

\section{b. Factors considered predictors of mortality at the moment of the study design, their identification and hierarchization}

The selection of the outcome measures that could be associated with the course of SS was initially based on what is reported in the literature regarding the potential impact of each of these on mortality from sepsis or SS. One example is the delay in the administration of an antibiotic therapy, which was described as an independent factor of an unfavorable clinical course, or the presence of shock.

Other outcome measures reported as relevant in studies of SS in the general population or having some clinical or demographic plausibility were also considered, such as age, previous nutritional status, having a chronic disease at the time of the event, the volume expansion administered during the first hours, or the presence of complications along the clinical course (e.g., ARDS).

Table 4 (Association between the clinical presentation or the treatment provided and mortality) shows a full list of potential predictive outcome measures. The statistical analysis describes the process of identification and hierarchization of outcome measures. The association between potential predictors and the primary endpoint (28-day mortality) was assessed using a bivariate and multivariate logistic regression analysis. Initially, a bivariate analysis between each of the selected independent outcome measures or predictors $(x)$ and the dependent outcome measure (y), 28-day mortality, was done. The existence of an individual association was observed through the change of raw $\beta$ coefficients and Wald test for each of them. In this stage, the cut-off point of $p$ was $<0.1$.

The following outcome measures were included in the multivariate analysis model: age, place of residence, nutritional status, severity at admission, concomitant disease, presence of shock, presence of ARDS, fluids $>60 \mathrm{~mL} / \mathrm{kg}$ within the first hour, use of vasoactive drugs, treatment with low-dose corticosteroids, selected based on a $p$ value of $>0.10$.

The final multivariate logistic regression model developed with a parsimonious model was robust and stable, and calibrated and discriminated adequately, with a Hosmer-Lemeshow test value of 0.67 and an area under the ROC (Receiver Operating Characteristic) curve of 0.76. 
ANNEX 2.

DATA COLLECTION RECORD

1. ID number:

2. Number of event:

3. Age: $\quad \square \square \square$ (in months)

4. Sex: $\square$ Male $\square$ Female

5. Date of admission at the hospital: $\square \square / \square \square / \square \square$

6. Date of admission at the ICU: $\square \square / \square \square / \square \square$

7. Regular residence:

$\square$ Rural

$\square$ Urban

8. History:

$\square$ Surgery: $\square$ Yes $\square$ No

Elective

Emergency

$\square$ Trauma: $\quad \square$ Yes $\square$ No

9. Weight (grams):

ㅁㅁㅁ

10. Length/Height (centimeters):

ㅁㅁ

11. Nutritional status

(visual impression if 11 and 12 could not be recorded):
$\square$ Adequate
Moderate malnutrition
Severe malnutrition

12. Comorbidities:

In case of more than one condition, record all of them.

$\square$ Neuromuscular disease

$\square$ Cardiovascular disease

$\square$ Respiratory disease

$\square$ Renal disease

$\square$ Gastrointestinal disease

$\square$ Hematologic disease (not cancer)

$\square$ Immunologic disease

$\square$ Extrinsic immunosuppression

$\square$ Transplant

$\square$ Cancer

Metabolic disease

$\square$ Chromosomal/genetic disease

$\square$ Other uncategorized, disabling chronic disease

$\square$ None 
13. Clinical characteristics of the episode of severe sepsis at the time of diagnosis (according to Tables 2, 3 and 4):

- SIRS ( 2 criteria, one of which must be one of the first two criteria)

\begin{tabular}{|l|cc|}
\hline & Yes & No \\
\hline Thermal deregulation & $\square$ & $\square$ \\
\hline $\begin{array}{l}\text { Leukocytosis, leukopenia or }>10 \% \\
\text { immature neutrophils }\end{array}$ & $\square$ & $\square$ \\
\hline $\begin{array}{l}\text { Tachycardia at any age or } \\
\text { bradycardia in children <1 year old }\end{array}$ & $\square$ & $\square$ \\
\hline Tachypnea or AMV & $\square$ & $\square$ \\
\hline
\end{tabular}

- Proven infection: $\quad \square$ Yes $\square$ No

- Suspected infection: $\square$ Yes $\square$ No

- Organ dysfunction (Table 4)

$\square$ Cardiovascular

$\square$ Respiratory

$\square$ Neurological

$\square$ Hematologic

$\square$ Renal

$\square$ Hepatic

- ARDS:

Yes $\square$ No

\begin{tabular}{|l|c|c|}
\hline & YES & NO \\
\hline $\mathrm{Pa} / \mathrm{Fi}<\mathbf{2 0 0}$ & & \\
\hline Bilateral infiltrates & & \\
\hline Acute beginning & & \\
\hline No signs of left heart failure & & \\
\hline
\end{tabular}

- Diagnosis of severe sepsis:

Upon admission to the PICU

Within the first $24 \mathrm{~h}$

Between 24 and $48 \mathrm{~h}$

$>48 \mathrm{~h}$

14. Severity of the disease:

- PIM2 
15. Treatment at the ICU (severe sepsis episode-septic shock):

- Resuscitation measures during the first 6 hours

- Expansions:

$\square$ Isotonic saline solution

$\square$ Gelatin

Starch

Albumin

Plasma

Other

Total amount in the first hour $(\mathrm{cc} / \mathrm{kg})$ :

$\checkmark$ Unknown:

- Total amount in the first 6 hours $(\mathrm{cc} / \mathrm{kg})$ :

$\checkmark$ Unknown:

- Vasoactive agents (in the first $6 \mathrm{~h}$ ):

(Specify the maximum dose in $\mu \mathrm{g} / \mathrm{kg} / \mathrm{min}$ only for the first 3 , if known)
Dopamine:
$\mu \mathrm{g} / \mathrm{kg} / \mathrm{min}$
$\mu \mathrm{g} / \mathrm{kg} / \mathrm{min}$
Adrenaline:
$\mu \mathrm{g} / \mathrm{kg} / \mathrm{min}$
Nitroprusside
Noradrenaline:
Nitroglycerin
Dobutamine
Phenylephrine
Milrinone
Other:

- Assisted ventilation (in the first $72 \mathrm{~h}$ ):

Traditional AMV

$\square$ High frequency

Non-invasive

- Renal function replacement (in the first $\mathbf{7 2} \mathrm{h}$ ):

Peritoneal dialysis

$\square$ Hemodialysis

$\square$ Hemofiltration

- Specific treatment (in the first $\mathbf{7 2} \mathrm{h}$ ):

Heparin

Albumin

Intravenous gamma globulin

Low-dose corticosteroids (replacement)

$\square$ High-dose corticosteroids

Insulin

$\square$ Other (specify):

- General treatment

- Antibiotics:

Yes

No

The first dose was administered within the first hour after diagnosis:

YES

NO $\square$ Unknown 
16. Patient's outcome:

- Organ dysfunction over time since the start of the episode

\begin{tabular}{|l|l|l|l|l|}
\hline Days of evolution & \multicolumn{1}{|c|}{$\mathbf{1}$} & $\mathbf{3}$ & $\mathbf{7}$ & 14 \\
\hline Date & & & & \\
\hline Cardiovascular & & & & \\
\hline Respiratory & & & & \\
\hline Neurological & & & & \\
\hline Hematologic & & & & \\
\hline Renal & & & & \\
\hline Hepatic & & & & \\
\hline
\end{tabular}

- Date of discharge from the PICU:

$\square \square / \square \square / \square \square$

$\square$ Alive

Dead

- Discharged from hospital?
$\square$ Alive
$\square$ Dead
Unknown

- Still in the PICU at $\mathbf{2 8}$ days after the start of the episode:

$\square$ Yes $\square$ No

- Patient's death is related to the severe sepsis episode:
Yes
$\square$ No
Unknown

- Patient's sequelae after discharge from the PICU or at 28 days:

- Oxygen-dependent: $\square$ Yes $\square$ No $\square$ Unknown

- Severe neurological dysfunction: $\square$ Yes $\square$ No $\square$ Unknown

- Chronic kidney injury: $\square$ Yes $\square$ No $\square$ Unknown

- Tube feeding: $\square$ Yes $\square$ No $\square$ Unknown

17. Characteristics of the infection:

- Origin of the infection

Community-acquired

PICU-acquired nosocomial

$\square$ Hospital-acquired nosocomial

Unknown

- Primary source of infection

Respiratory

Endocarditis

Genitourinary

By devices

Abdominopelvic

Primary bacteremia

Skin, cell tissue

Other

Bone, joint

Unknown

Central nervous system (CNS) 

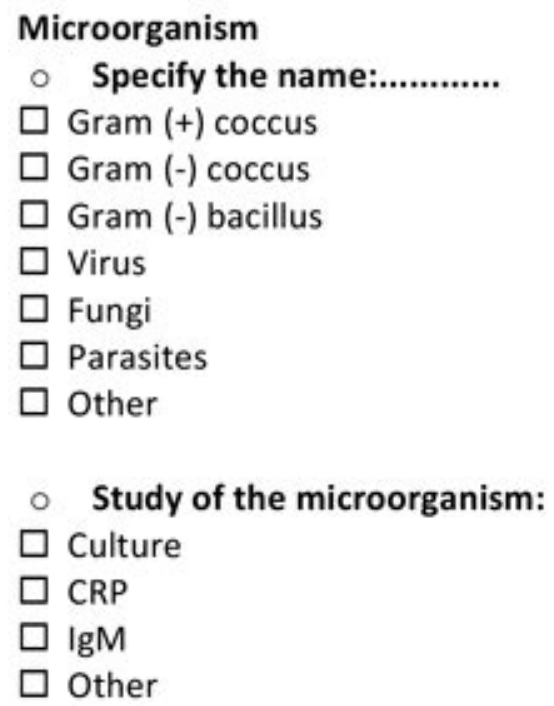

\section{- Place found:}

$\square$ Blood

$\square$ Urine

$\square$ Cerebrospinal fluid (CSF)

$\square$ Bronchoalveolar lavage (BAL), mini-BAL

$\square$ Pulmonary secretions

$\square$ Focus puncture

$\square$ Pleural fluid

$\square$ Devices

$\square$ other

\section{- Resistance:}

$\square$ Methicillin-resistant staphylococcus

$\square$ Vancomycin-resistant enterococcus

$\square$ Gram (-) bacilli, ESBL+

$\square$ No microorganism identification 


\section{ANNEX 3. \\ DISTRIBUTION OF PARTICIPATING PEDIATRIC INTENSIVE CARE UNITS}

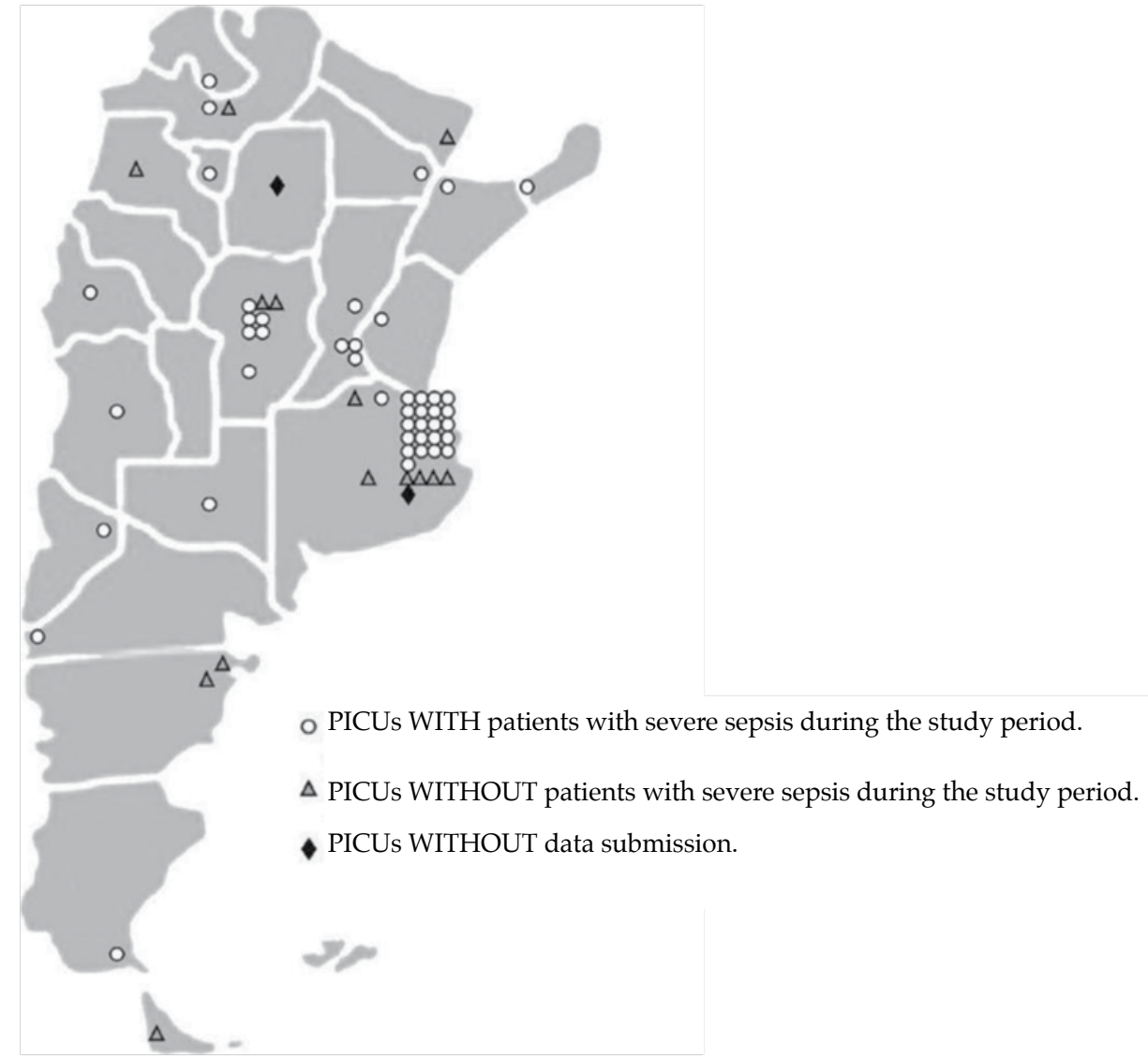

PICU: pediatric intensive care unit. 
ANNEX 4.

AREA UNDER THE ROC CURVE $=\mathbf{0 . 7 6}$.

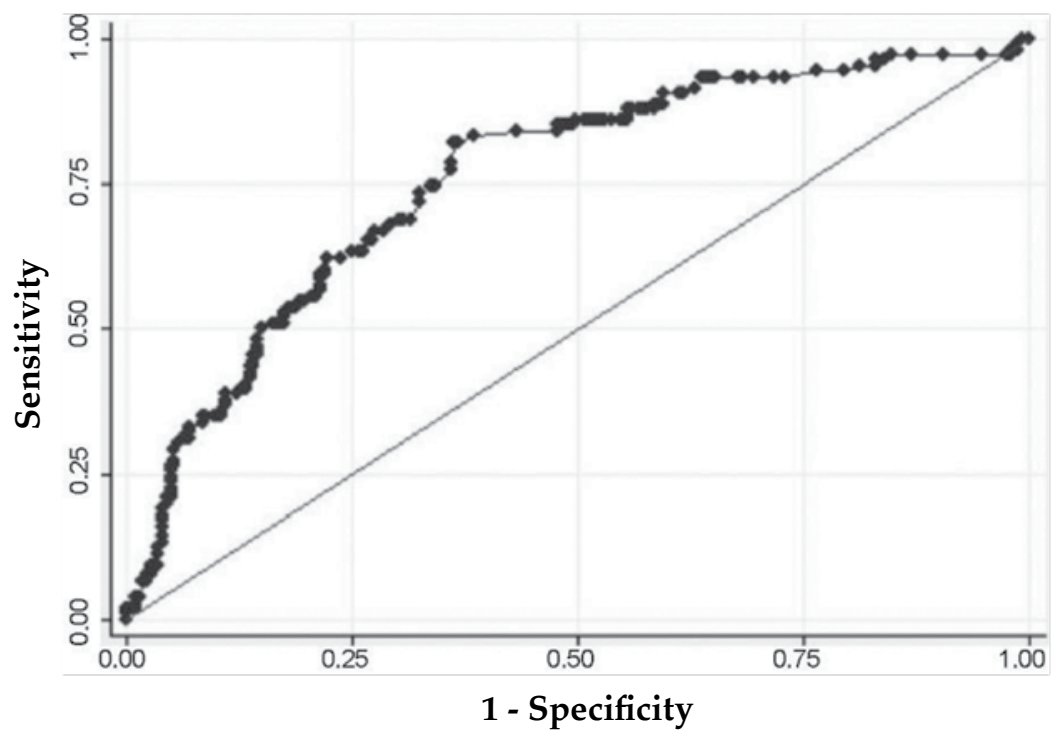

Area under the curve $=0.7592$ 